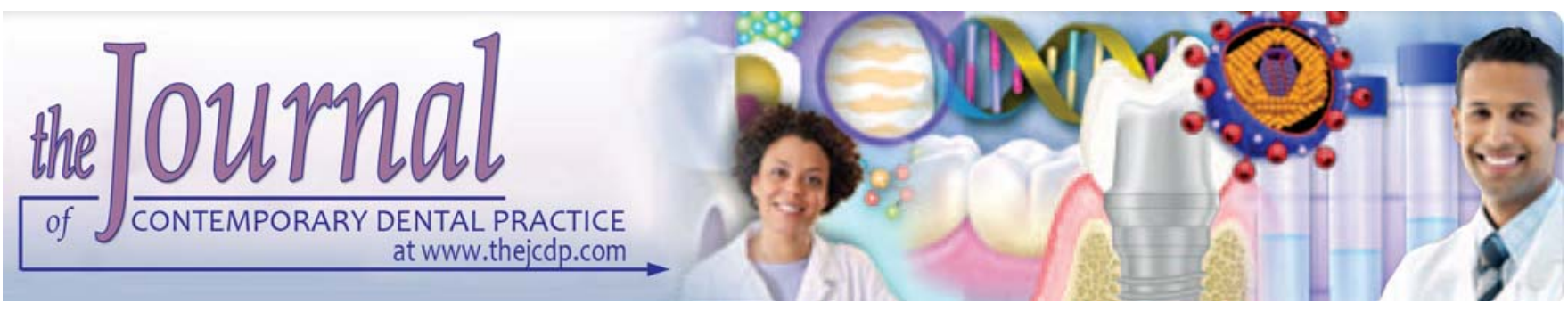

\title{
Evaluation of Interference of Calcium Hydroxide-based Intracanal Medication in Filling Root Canal Systems
}

Deyla Duarte Vilela, Manoel Matos Neto, Alexandre Mascarenhas Villela, Matheus Melo Pithon

\begin{abstract}
Aim: To evaluate the interference of the intracanal medication Calen ${ }^{\circledR}$ (SSWhite, São Paulo, Brazil) on the filling of simulated lateral canals.

Materials and methods: Twenty human anterior teeth were used. Before the endodontic filling procedures the access of cavity was made, and after this root canals were made in all the teeth to simulate the presence of lateral canals. After preparation, the teeth were randomly divided into two groups $(n=10)$. In group I, the root canal system was filled directly after chemicalmechanical preparation; in group II, endodontic treatment was performed in multiple sessions, and after preparation the calcium hydroxide-based intracanal medication Calen ${ }^{\circledR}$ was inserted. After the period of 7 days, the root canals were vigorously irrigated and then they were filled. Next, the teeth were radiographed to verify the quality of the filling.
\end{abstract}

Results: The results demonstrated that the teeth treated in a single session, without calcium hydroxide medication, presented 47 canals out of 60 with radiographic evidence of filling, whereas the teeth in which intracanal medication was used, only 07 presented a radiographic image compatible with filling $(p<0.05)$.

Conclusion: The use of the calcium hydroxide-based medication Calen made it difficult to obtain a hermetic filling of the root canal system.

Clinical significance: The clinical significance of this work basing on the fact that once the dentist knowing that property obliteration of calcium hydroxide can be taken care when they are used in the presence of lateral canals.

Keywords: Root canal systems, Calcium hydroxide, Intracanal medication.

How to cite this article: Vilela DD, Neto MM, Villela AM, Pithon MM. Evaluation of Interference of Calcium Hydroxide-based Intracanal Medication in Filling Root Canal Systems . J Contemp Dent Pract 2011;12(5):368-371.

Source of support: Nil

Conflict of interest: None declared

\section{INTRODUCTION}

The presence of serous or purulent exudate makes it necessary to perform endodontic treatment in multiple sessions. ${ }^{1}$ This makes it imperative to use intracanal medication and a material is being sought which is shown to be as innocuous to and biocompatible as possible with the surrounding tissues, with the purpose of potentiating the process of disinfecting the dentinal tubule system. ${ }^{2-6}$ The choice of calcium hydroxide $\left[\mathrm{Ca}(\mathrm{OH})_{2}\right]$ as intracanal medication has been almost unanimous. ${ }^{2-6}$

Calcium hydroxide $\left[\mathrm{Ca}(\mathrm{OH})_{2}\right]$ is advocated as an interappointment endodontic therapeutic dressing because of its antibacterial effect on most of the microorganisms identified in the root canal system., ${ }^{7,8}$ It was found that $\mathrm{Ca}(\mathrm{OH})_{2}$ dressing for 7 days efficiently eliminate bacteria that survive root canal instrumentation ${ }^{9}$ pointed out that the use of $\mathrm{Ca}(\mathrm{OH})_{2}$ for 7 days, with subsequent instrumentation and irrigation with sodium hypochlorite, improved the debridement of the root canal system. After its use, $\mathrm{Ca}(\mathrm{OH})_{2}$ should be completely removed from the root canal walls to obtain an adequate permanent root canal obturation. ${ }^{10}$

The hypothesis of this work is that after its use $\mathrm{Ca}(\mathrm{OH})_{2}$ can not be removed completely from within root canals. Thus, the objective of the present article was to evaluate the interference of the intracanal medication Calen ${ }^{\circledR}$ (SSWhite, São Paulo, Brazil) in the filling of simulated lateral canals, by means of the thermoplasticization technique.

\section{MATERIALS AND METHODS}

In this study, 20 extracted human anterior teeth, from the bank of human teeth (BDH) at the State University of Southwest Bahia, UESB, being units or healthy caries or restorations since that would keep the pulp chamber and preserved coronary anatomy with fully formed apices. During the selection of teeth periapical radiographs were taken with a digital sensor (Schick Technologies, Inc. Long Island City, New York, USA) to exclude dental units with apexes in training, torn root, root canals obliterated lines of fracture, internal resorption and external and internal 
variations of dental anatomy. The teeth were cleaned and preserved in $10 \%$ formaldehyde solution. At the time of use, they were washed under running water for 1 hour and dried with gauze.

Before the endodontic filling procedures, an access cavity was made according to the technique recommended by Siqueira JR, 2002. ${ }^{11}$ The instrumentation limit was determined individually by introducing a K-type file \#10 (Maillefer), whose extremity coincided with the apical foramen, which was observed with the aid of a loupe at $4 \times$ magnification (Bio-Art, São Paulo, Brazil). The working length was calculated by withdrawing the file to $1 \mathrm{~mm}$ short of this measurement. After obtaining the measurement, the instrumentation technique proposed by Siqueira Jr was used (2002),${ }^{11}$ by which all the teeth were instrumented up to K-type file \#45 (Maillefer). After instrumentation, maintenance of the apical foramen patency was verified with a K-type file \#15 (Maillefer). Irrigation was performed with $2.5 \%$ sodium hypochlorite (sanitary solution Q-BOA ${ }^{\circledR}$ ), alternately to using the instruments. On conclusion of the preparation, in order to remove the smear-layer, the entire root canal was filled with 17\% ETDA (A Fórmula Farmácia de manipulação, Bahia, Brazil) and agitated in the canal with a lentulo drill \#40 (Maillefer) driven by a micromotor, for 30 seconds. This solution remained at rest in the canal for 5 minutes. After this procedure, the root canals were again irrigated with $2.5 \%$ sodium hypochlorite (sanitary solution Q-BOA ${ }^{\circledR}$ ). The root canals were dried with absorbent paper cones (Tanari - Tanariman Industrial, Ltda., Amazonas, Brazil).

After this, canals were made in the roots of all the teeth to simulate the presence of lateral canals, with the aid of a $21 \mathrm{~mm}$ long K-type file \#10 (Maillefer), calibrated No. 20, and adapted for use on the micromotor. Six canals were created in each tooth, three being in the mesial and three in the distal region, with a $3 \mathrm{~mm}$ distance between them on both proximal faces starting from the apex.

After preparation, the teeth were randomly divided into two groups $(\mathrm{n}=10)$.

Group I: The root canals were filled directly after chemical mechanical preparation $(\mathrm{n}=10)$.

Group II: Endodontic treatment was performed in multiple sessions and after preparation the calcium hydroxide-based intracanal medication Calen ${ }^{\circledR}$ (SSWhite, São Paulo, Brazil) was inserted with the aid of an ML syringe (SSWhite/Duflex, São Paulo, Brazil). The intracanal medication was inserted until it appeared in the apical foramen. After the period of 7 days, the root canals were irrigated vigorously with $2.5 \%$ sodium hypochlorite (sanitary solution Q-BOA ${ }^{\circledR}$ ) and 17\% EDTA (A Fórmula), agitated inside the canal with a lentulo drill \#40 (Maillefer) driven by a micromotor, for 30 seconds. This solution remained at rest in the canal for 5 minutes, and immediately afterward the canal was irrigated with $2.6 \% \mathrm{NaOCl}$ (sanitary solution Q-BOA ${ }^{\circledR}$ ) and then the filling itself was inserted.

To fill the root canals, the vertical condensation technique was used. In all the groups, Microtipped ${ }^{\circledR}$ M gutta percha cones (Endo Points Indústria e Comércio Ltda., Rio de Janeiro, Brazil) were used, their tips being calibrated with a calibration ruler (Maillefer) No. 45 adapted for the purpose of filling. The cones were tested inside the canals until they reached the apical limit of filling, in a firm manner, without undergoing deformations. Once the main cone was chosen, the filling itself was performed, using filling cement Sealer $26^{\circledR}$ (Dentsply Indústria e Comércio Ltda., Rio de Janeiro, Brazil) for this purpose.

On conclusion of filling the canals, digital radiographs were taken in the vestibular-lingual direction, to evaluate the presence of radiopacity, characteristic of filling in the root canals, and to verify whether there was an image compatible with the presence or absence of filling in the simulated lateral canals.

This percentage was recorded and the data submitted to statistical evaluation by the nonparametric Chi-square test, after analysis, when comparisons of the groups, and within the same group were made.

\section{RESULTS}

In group I, in which the teeth were treated in a single session, in a total of 60 simulated lateral canals, 47 canals presented radiographic evidence of filling; representing a percentage of $60 \%$ of those located at $3 \mathrm{~mm}$ from the apex, $90 \%$ of those at $6 \mathrm{~mm}$ and $85 \%$ of those at $9 \mathrm{~mm}$ from the root apex, as shown in Table 1 and Figures $1 \mathrm{~A}$ and B.

Whereas in group II, with the intracanal medication used, of the total number of 60 simulated lateral canals, 7 presented a radiographic image compatible with filling of the root canal system; with a percentage of $5 \%$ of those located at $3 \mathrm{~mm}, 25 \%$ of those located at $6 \mathrm{~mm}$ and $5 \%$ of those that were $9 \mathrm{~mm}$ from the root apex, as shown in Table 2 and Figures 2A and B.

\begin{tabular}{|c|c|c|c|c|c|c|}
\hline \multirow[t]{2}{*}{ Teeth } & \multicolumn{2}{|c|}{$\begin{array}{l}\text { At } 3 \mathrm{~mm} \\
\text { from the apex }\end{array}$} & \multicolumn{2}{|c|}{$\begin{array}{l}\text { At } 6 \mathrm{~mm} \\
\text { from the apex }\end{array}$} & \multicolumn{2}{|c|}{$\begin{array}{l}\text { At } 9 \mathrm{~mm} \\
\text { from the apex }\end{array}$} \\
\hline & Canal 1 & Canal 2 & Canal 1 & Canal 2 & Canal 1 & Canal 2 \\
\hline 1 & Yes & Yes & Yes & Yes & Yes & Yes \\
\hline 2 & No & No & Yes & No & No & No \\
\hline 3 & Yes & Yes & Yes & Yes & Yes & Yes \\
\hline 4 & Yes & Yes & Yes & Yes & Yes & Yes \\
\hline 5 & Yes & No & Yes & No & Yes & No \\
\hline 6 & Yes & Yes & Yes & Yes & Yes & Yes \\
\hline 7 & No & No & Yes & Yes & Yes & Yes \\
\hline 8 & Yes & Yes & Yes & Yes & Yes & Yes \\
\hline 9 & No & No & Yes & Yes & Yes & Yes \\
\hline 10 & No & Yes & Yes & Yes & Yes & Yes \\
\hline & \multicolumn{2}{|c|}{$20 \rightarrow 60 \%$} & \multicolumn{2}{|c|}{$20 \rightarrow 90 \%$} & \multicolumn{2}{|c|}{$20 \rightarrow 85 \%$} \\
\hline
\end{tabular}




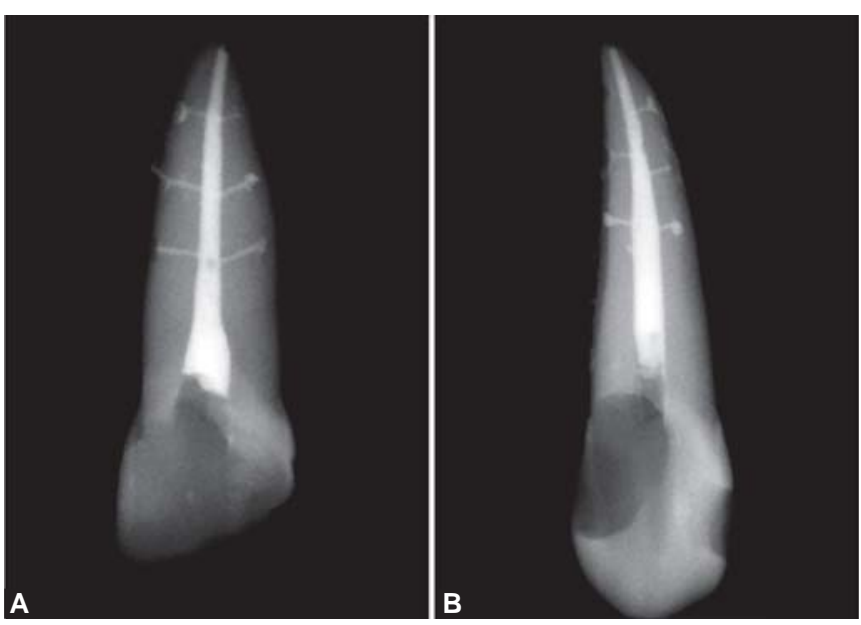

Figs $1 \mathrm{~A}$ and B: Radiographed teeth from group I

\begin{tabular}{|c|c|c|c|c|c|c|}
\hline \multirow[t]{2}{*}{ Teeth } & \multicolumn{2}{|c|}{$\begin{array}{l}\text { At } 3 \mathrm{~mm} \\
\text { from the apex }\end{array}$} & \multicolumn{2}{|c|}{$\begin{array}{c}\text { At } 6 \mathrm{~mm} \\
\text { from the apex }\end{array}$} & \multicolumn{2}{|c|}{$\begin{array}{l}\text { At } 9 \mathrm{~mm} \\
\text { from the apex }\end{array}$} \\
\hline & Canal 1 & Canal 2 & Canal 1 & Canal 2 & Canal 1 & Canal 2 \\
\hline 1 & No & No & No & No & No & No \\
\hline 2 & No & No & Yes & Yes & No & Yes \\
\hline 3 & No & No & Yes & No & No & No \\
\hline 4 & No & No & No & No & No & No \\
\hline 5 & No & No & No & No & No & No \\
\hline 6 & No & No & No & Yes & No & No \\
\hline 7 & No & No & No & No & No & No \\
\hline 8 & No & No & No & Yes & No & No \\
\hline 9 & No & No & No & No & No & No \\
\hline \multirow[t]{2}{*}{10} & No & Yes & No & No & No & No \\
\hline & \multicolumn{2}{|c|}{$20 \rightarrow 5 \%$} & \multicolumn{2}{|c|}{$20 \rightarrow 25 \%$} & \multicolumn{2}{|c|}{$20 \rightarrow 5 \%$} \\
\hline
\end{tabular}
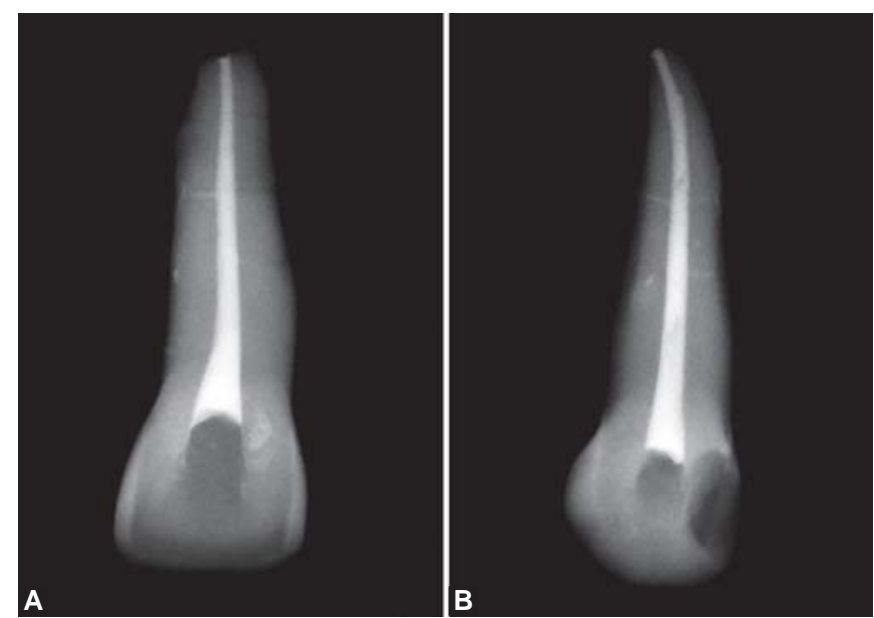

Figs 2A and B: Radiographed teeth from group II (Calen $\left.{ }^{\circledR}\right)$

The number of lateral canals that radiographically presented the highest percentage of filling was found in the group in which the calcium hydroxide intracanal medication was not used, and therefore, the teeth were treated in a single session.

According to the above-mentioned tables, statistically significant difference $(\mathrm{p}<0.05)$ was verified only in the same variables between groups. In the others, there was no statistically significant difference $(\mathrm{p}>0.05)$ (Tables 3 to 5$)$.

$\begin{aligned} & \text { Table 3: Group I - comparisons among the variables of } \\
& \text { the same group }\end{aligned}$
\begin{tabular}{cc} 
Distances from the root apex & Level of statistical significance \\
\hline $3 \times 6 \mathrm{~mm}$ & $\mathrm{p}=0.068$ \\
$3 \times 9 \mathrm{~mm}$ & $\mathrm{p}=0.157$ \\
$6 \times 9 \mathrm{~mm}$ & $\mathrm{p}=1.000$ \\
\hline
\end{tabular}

Table 4: Group II - comparisons among the variables of the same group

\begin{tabular}{cr}
\hline Distances from the root apex & Level of statistical significance \\
\hline $3 \times 6 \mathrm{~mm}$ & $\mathrm{p}=0.184$ \\
$3 \times 9 \mathrm{~mm}$ & $\mathrm{p}=0.468$ \\
$6 \times 9 \mathrm{~mm}$ & $\mathrm{p}=0.184$ \\
\hline
\end{tabular}

Table 5: Group I × group II - comparisons between the same variables between groups

\begin{tabular}{lr}
\hline Distances from the root apex & Level of statistical significance \\
\hline $3 \mathrm{~mm} \rightarrow$ group I $\times$ group II & $p=0.000$ \\
$6 \mathrm{~mm} \rightarrow$ group I $\times$ group II & $p=0.000$ \\
$9 \mathrm{~mm} \rightarrow$ group I $\times$ group II & $p=0.000$ \\
\hline
\end{tabular}

\section{DISCUSSION}

In endodontic therapy, filling in conjunction with cleaning and shaping the root canal system are fundamental for successful treatment. Residues of calcium hydroxide-based intracanal medication have influenced root filling with gutta percha by increasing apical leakage. ${ }^{12}$ Thus, the proposal of the present article was to evaluate the interference of the intracanal medication Calen ${ }^{\circledR}$ (SSWhite) in the filling of simulated lateral canals, by means of the thermoplasticization technique.

De Deus ${ }^{12}$ reported the presence of lateral canals in $27.4 \%$ of 1140 teeth studied: $17 \%$ were located in the apical third, $8.8 \%$ in the middle third and $1.6 \%$ in the coronal third.

For this evaluation, the methodology proposed by Goldberg et al in 2002 was used, ${ }^{13}$ which consists of creating artificial lateral canals before the filling procedures. While creating artificial channels that diverge rather than actually occurs, this method allows you to standardize the channels, allowing to compare methods of filling that could hardly be realized in natural teeth with lateral canals, because of the multitude of formats and locations that they may have.

Several studies reported that $\mathrm{Ca}(\mathrm{OH})_{2}$ may have the capacity to block dentinal tubules. ${ }^{4,10}$ The results obtained were unfavorable with regard to removal of the calcium hydroxide medication (Calen ${ }^{\circledR}$ ) used, which according to the radiographic evaluation, interfered in the filling of the simulated lateral canals. The teeth were treated in one session, presented a rate of $60 \%$ filling of lateral canals located $3 \mathrm{~mm}$ from the apex, 90\% for those $6 \mathrm{~mm}$ and $85 \%$ 
for those who were $9 \mathrm{~mm}$ from the apex. In the group where it was used intracanal medication, there was filling of only $5 \%$ for the lateral canals located $3 \mathrm{~mm}, 25 \%$ for those $6 \mathrm{~mm}$ and 5\% for those who were $9 \mathrm{~mm}$ from the apex, these results are quite representative of the difficulty in filling the lateral canals after using calcium hydroxide. For all tested groups, the number of nonfilled or partially filled lateral canals was larger in the apical third. This finding is clinically important because it is well known that there is a greater percentage of lateral canals in the apical third of the root.

This difficulty in removing the calcium hydroxide intracanal medication corroborates the study of Lambrianidis et al (2006) $)^{14}$ and Goldberg et al (2002) ${ }^{13}$ in which none of the techniques used removed the intracanal dressing efficiently.

With the purpose of removing the $\mathrm{Ca}(\mathrm{OH})_{2}$, before the filling procedure, the canal was irrigated with EDTA followed by irrigation with $\mathrm{NaOCl}$, and these materials were used by virtue of the findings of Calt and Serper in 1999, ${ }^{15}$ who achieved complete removal of $\mathrm{Ca}(\mathrm{OH})_{2}$ from the canals, making it possible for the cement to penetrate into the dentinal tubules. ${ }^{15}$ In the present study, however, this efficiency with regard to removing the calcium hydroxide medication (Calen ${ }^{\circledR}$ ) used, was not observed.

According to Margelos et $\mathrm{al}^{16}$, many questions relating to the use of $\mathrm{Ca}(\mathrm{OH})_{2}$ as an intracanal medication still have to be answered. We believe that the findings obtained in our study point out another side effect to consider when selecting $\mathrm{Ca}(\mathrm{OH})_{2}$ as an interappointment dressing in root canal therapy. This is an important clinical aspect to be considered avoiding remission of endodontic problems.

\section{CONCLUSION}

According to the methodology used and the results obtained in this study, it could be concluded that

1. The use of calcium hydroxide-based intracanal medication made it difficult to obtain hermetic filling of the root canal system, since it obliterated the simulated lateral canal entrances.

2. The number of simulated lateral canals filled when intracanal medication was not used was higher than it was when the medication was used.

\section{REFERENCES}

1. Tanomaru JM, Tanomaru-Filho M, Hotta J, Watanabe E, Ito IY. Antimicrobial activity of endodontic sealers based on calcium hydroxide and MTA. Acta Odontol Latinoam 2008;21:147-51.

2. Flanagan D. Calcium hydroxide paste as a surface detoxifying agent for infected dental implants: Two case reports. J Oral Implantol 2009;35:204-09.

3. Kostic MM, Krunic NS, Krunic BJ. Effect of calcium hydroxide based desensitizing agent on cast crown retention. Stomatologiia (Mosk) 2009;88:58-60.
4. Noetzel J, Nonhoff J, Bitter K, Wagner J, Neumann K, Kielbassa AM. Efficacy of calcium hydroxide, Er:YAG laser or gaseous ozone against Enterococcus faecalis in root canals. Am J Dent 2009;22:14-18.

5. Sepet E, Pinar A, Ilhan B, Ulukapi I, Bilir A, Tuna S. Cytotoxic effects of calcium hydroxide and mineral trioxide aggregate on 3T3 fibroblast cell line in vitro. Quintessence Int 2009;40: e55-61.

6. Turk BT, Sen BH, Ozturk T. In vitro antimicrobial activity of calcium hydroxide mixed with different vehicles against Enterococcus faecalis and Candida albicans. Oral Surg Oral Med Oral Pathol Oral Radiol Endod 2009;108:297-301.

7. Bystrom A, Claesson R, Sundqvist G. The antibacterial effect of camphorated paramonochlorophenol, camphorated phenol and calcium hydroxide in the treatment of infected root canals. Endod Dent Traumatol 1985;1:170-75.

8. Sjogren U, Figdor D, Spangberg L, Sundqvist G. The antimicrobial effect of calcium hydroxide as a short-term intracanal dressing. Int Endod J 1991;24:119-25.

9. Metzler RS, Montgomery S. Effectiveness of ultrasonics and calcium hydroxide for the debridement of human mandibular molars. J Endod 1989;15:373-78.

10. Porkaew P, Retief DH, Barfield RD, Lacefield WR, Soong SJ. Effects of calcium hydroxide paste as an intracanal medicament on apical seal. J Endod 1990;16:369-74.

11. Siqueira JF Jr, Rocas IN, Favieri A, Machado AG, Gahyva SM, Oliveira JC, et al. Incidence of postoperative pain after intracanal procedures based on an antimicrobial strategy. J Endod 2002;28:457-60.

12. Kim SK, Kim YO. Influence of calcium hydroxide intracanal medication on apical seal. Int Endod J 2002;35:623-28.

13. Goldberg F, Artaza LP, De S. Influence of calcium hydroxide dressing on the obturation of simulated lateral canals. J Endod 2002;28:99-101.

14. Lambrianidis T, Kosti E, Boutsioukis C, Mazinis M. Removal efficacy of various calcium hydroxide/chlorhexidine medicaments from the root canal. Int Endod J 2006;39:55-61.

15. Calt S, Serper A. Dentinal tubule penetration of root canal sealers after root canal dressing with calcium hydroxide. J Endod 1999;25:431-33.

16. Margelos J, Eliades G, Verdelis C, Palaghias G. Interaction of calcium hydroxide with zinc oxide-eugenol type sealers: A potential clinical problem. J Endod 1997;23:43-48.

\section{ABOUT THE AUTHORS}

\section{Deyla Duarte Vilela}

Student, Department of Endodontics, Dental Center for the Study of Bahia (CEBEO), Bahia, Brazil

\section{Manoel Matos Neto}

Professor, Department of Health, Southwest Bahia University (UESB) Bahia, Brazil

\section{Alexandre Mascarenhas Villela}

Professor, Department of Endodontics, Dental Center for the Study of Bahia (CEBEO), Bahia, Brazil

\section{Matheus Melo Pithon (Corresponding Author)}

Professor, Department of Health, Southwest Bahia University (UESB) Bahia, Brazil, e-mail: matheuspithon@gmail.com 